Open Access

\title{
Visual narrative methodology in educational research with babies: triadic play in babies' room
}

\author{
Avis Ridgway*, Liang Li and Gloria Quiñones
}

\author{
* Correspondence: avis.ridgway@ \\ monash.edu \\ Faculty of Education, Monash \\ University, Melbourne, Australia
}

\begin{abstract}
This paper examines an experimental technique that uses visual narrative methodology and dialogue commentary to create an effective research methodology for a pilot project studying babies and toddlers in long day care centres and family contexts. Researchers from different cultural backgrounds using video technology, formed the team of chief investigators. One video clip was chosen to make independent descriptions, comments and interpretations of what was noticed. Later, initial visual narrative descriptions were shared and extended after reading one another's responses. This process created a dialogue commentary that enabled data overview, interpretative analyses and synthesis supported by snapshot moments taken from video clip. One aim of the project was to visually capture the cultural worlds and transitory relationships of babies and toddlers. Researchers showed the selected video clip separately to babies' room educator, centre director, and parents recording their responses. Using visual narrative methodology, dialogue commentary, and a shared cultural historical theoretical framework, revealed useful contradictions that raised social and cultural questions such as: How do educators recognize cultural worlds and transitory relationships of babies and toddlers? How are transitory moments related to pedagogically by educators? Integrating researchers' personal, cultural and affective responses, affords new critical cultural perspectives. This paper draws on screen capture snapshot moments from one video clip, taken from babies' pilot project data. These offer small windows into methodological approaches used to research the cultural world and transitory moments of three infants and their educator, located in the babies' room of an Australian long day care (LDC) site.
\end{abstract}

Keywords: Visual narrative methodology, Dialogue commentary, Babies-Toddlers, Triadic play

\section{Introduction}

Recently, visual methodology has been applied by many researchers to explore the world of young babies by trying to capture their 'voices' through viewing moments of action (Sumsion et al. 2014; Bitou and Waller 2011; White 2011; Sikder and Fleer 2015). The notion of young children's 'voice' is understood metaphorically as it acknowledges the young child as being capable, and having a thinking, meaning making, yet unspoken understanding of their world.

(c) 2016 The Author(s). Open Access This article is distributed under the terms of the Creative Commons Attribution 4.0 International License (http://creativecommons.org/licenses/by/4.0/), which permits unrestricted use, distribution, and reproduction in any medium, provided you give appropriate credit to the original author(s) and the source, provide a link to the Creative Commons license, and indicate if changes were made. 
Kupfer (2011) for example, argued that "children's voice is recognized as an important attribute of a living being that informs others about where the child is -physically and mentally- and how she/he feels" (p.102). Different research approaches to capture the perspective of children's 'voice', include the use of digital visual technologies, (such as screen capture snapshots) which can create conditions that may encourage the young child's engagement in the research. For example, in order to record babies' perspectives in their infant-toddler project, Sumsion et al. (2011) used "baby cam", a micro video camera system worn on a headband by an infant. This offered a new way of recording and re-viewing infants' visual experiences. Interpretations of these experiences however, were generally 'voiced' from the adult or researcher's perspective. White (2011), in her attempts to capture infant voice, used a dialogical approach to explore infant-toddler's everyday events from their perspective. White (2011), p. 64 as a dialogic researcher, suggested 'voice' may include 'visual acts of social engagement with others'. Her research strongly argued why it is important to "enable a focus on the interested experience of 'other' rather than consummated truth claims by the lone researcher" (p. 64). A polyphonic video technique applied by White to capture toddler's daily activities from multiple angles, enabled research participants to develop "multiple modes of communication" (2011, p.79) for more fully sensing the experience and understanding the perspective of 'other'. Quiñones and Fleer suggest "it is the theoretical gaze we adopt that shapes how researchers make sense of the data we capture" (Johanssen and White, 2011 p.7). The need to establish a theoretical gaze for "understanding what life is like for children in Early Childhood Education and Care (ECEC) settings, from the perspectives of the infants themselves" (p.316) is also flagged by Sumsion and Goodfellow (2012) who encourage researchers of infants to engage with a diversity of ways of "looking and listening in" (p.316). In particular, their belief in the value of bringing together many different perspectives into "productive dialogue" (p.315) is congruent with White's research that demanded multiple frames of reference, in order to orient researchers towards a dialectical reading of visual narrative data. Looking further, Quiñones and Fleer (2011), argued that when researching very young children, researchers should not only consider looking in and listening to "verbal communication but also understand the child's many different forms of expressing non-verbal emotions and meanings" (p.127). With this in mind they suggested using 'Visual Vivencias' as a methodological tool to understand the young child's emotional lived experience and sense of everyday events, thereby drawing researcher's attention "to the dialectical relations between the unity of the child and the social environment" (Johansson 2011 p.9). This further enriches our understanding of what capturing the young child's 'voice' means. When researchers attempt to capture the lived experiences and sense of everyday events from the young child's perspective through the use of visual methodologies, they acknowledge the unspoken 'voice' of the child which is always present in their affective active engagement with others and the environment (Malloch \& Trevarthen 2009; Rinaldi 2000; Selby \& Bradley 2003).

As will be shown, the experimental methodologies of visual narratives and dialogue commentary used in our babies and toddlers' research project, enabled us to focus on their affective engagement in daily transitory moments of action and identify the pedagogical strategies that supported their education. Our methodologies included snapshot selection from video. This allowed closer visual examination of infant's dynamic movement in their everyday life in the babies' room of a long day care (LDC) site, where educator Jane and three toddlers Elvin, Fay and Josh, were videoed. Table 1 overview shows site participant 
Table 1 Overview of case example setting and participants

\begin{tabular}{llll}
\hline Adults & Children & Site & Researchers \\
\hline Babies' room educator (Jane) & Elvin 16 months & Urban Long Day Care & Research team (L, G, A) \\
& Fay 21 months & Center in Australia & $\begin{array}{l}\text { University Human ethics } \\
\text { approval CF14/2789 - 2014001543 }\end{array}$ \\
Centre director (Kate) & Josh 18 months & & \\
Researcher (A.) & Focus child Elvin & Babies Room & Orient director to project. \\
& & Obtain permissions. \\
& & Video infants \\
& & Conduct interviews. \\
& & Screen capture snapshot \\
& & moments from video for analysis.
\end{tabular}

detail of the case example used in this paper, drawn from the pilot project - Studying Babies and Toddlers: Cultural Worlds and Transitory Relationships. Approvals from infants' parents and LDC director Kate were given and approximately $20 \mathrm{~h}$ of pilot site video data relating to activity of focus child Elvin, was taken.

The theoretical and methodological framework adopted in an Australian context for the pilot study of babies and toddlers, from which our case example was taken, is introduced next.

\section{Theoretical and methodological framing}

Theory informs the conceptualization of the study design methodology. "One of the strongest reasons for using cultural-historical theory is that it is not a reductive or static theory but renewable and expansive" (Ridgway et al. 2015 p.7). Vygotsky (1987) utilized the dialectical method and took a psychological view to the study of human consciousness and development. Specifically, he applied the dialectical method to the genesis of thought and language (Vygotsky 1987). In dialectical studies of child development the aim is to investigate the contradictory unity of the opposite aspects and tendencies of the child's social situation in order to find possibilities and conditions for their development ( $\mathrm{Li}$ 2014). Taking a dialectical-interactive research approach creates conditions to study infant's activities in the social practices of their everyday life, and illuminates participants' differing perspectives. A dialectical-interactive research approach includes accounting for the affective nature of infants' relationship to their environment, community, and the educational institutions in which they participate. Examining these relationships in this pilot project, required working sensitively using a wholeness approach that included using visual methods with the researched persons and building trust within the activity site (Quiñones 2014). In this spirit, as shown in Table 1, the research team provided an orientation to the pilot project for site director that ensured clear understanding of mutual benefits and requirements. Trusting relationships were built up over time through sensitive and culturally responsive communication by research team, in their educational and social contacts with LDC director, business manager and staff.

In relation to research methodology, Denzin and Lincoln (2003) argued for "multiple methods as a way of capturing as much of reality as possible" (p.11). In this paper, we utilized cultural- historical research approaches to better understand young children's 
transitory everyday moments and entered the methodological process by creating visual narratives from a video clip. Visual narratives involved sharing a story of the dynamic actions of participants by stablizing them for analysis through creating screen capture snapshots. Selected snapshot moments when placed together with researchers' observations of one video clip, and reflective interview data from educator and center director, can form a visual narrative.

Visual narrative methodology involved the research team bringing together visual data with their dialogue commentary and video transcripts. This juxtapositional movement of data permitted dialectical thinking around infants' everyday life activities that showed any qualitative change in their actions, which supported research team understanding of their experiences. Visual narrative methodology expanded capacity to interpret tensions between intersecting motives and ideas in data, and provided fresh research perspectives in particular through researchers' shared analysis of the visual data. The content of dialogue commentary was able to reflect different ideas, impressions and interpretations of the dynamics of videoed activity including verbal and nonverbal forms of expression. Using a dialectical- interactive research methodology aimed to contextualize the complexity of infant's everyday activities within their associated institutional practices and social situations (Hedegaard 2008).

\section{Video observations of infants' everyday transitory moments}

Quiñones (2014) noted visual methodologies "offer a new and complex way of researching and can offer a complex picture" (p.112). As an area considered difficult to study before ready availability of digital visual technology (Johansson and White 2011; Sumsion et al. 2014), researchers can now be closer to what Johansson (2011), p.43 referred to as the young child's "horizon". Using a video camera to continuously follow a focus child over a full day in the LDC site, researchers were well positioned to discover the numerous small everyday transitions that constantly occur for infants over a whole day. The method of continuous and uninterrupted filming used to track transitory activities of a focus infant, allowed possibilities for understanding pedagogical dimensions of collectivity and group interaction and, at the same time, also heightened the need for researcher sensitivity to social contexts present in the site. The video clip selected for our case example (and used in reflective interviews), gave only a tiny window into how the social and physical environment provided pedagogical influences that helped infants make meaning and choices for themselves. In uninterrupted video filming sessions for the wider pilot project, researchers could also appreciate how carefully designed site environments offered qualitatively different interactive spaces for infant play. This gave further context and interpretative opportunity for developing pedagogical insight into affective play environments for infant education. With these perspectives in mind, researchers looked more closely at the collective, imaginary and emotional nature of participatory action captured in the video clip and then focused carefully on these through the use of a series of screen capture snapshots of transitory moments (Figs. 1, 2, 3, 4 and 5).

Video observations of any infant-toddler transitory moment of inclination and interest within their room environment, may support researchers' interpretation of affective transformations in individual and collective social contexts. In our selected video clip (and subsequent snapshots) a particular 'lived momentum' (Ferholt 2010, p.78) was 
observed. We saw this as perezhivanie experienced by the three infants, with educator and researcher. 'Perezhivanie is always associated with processes, functions, and relationships that are emotionally relevant for the person. Any creative and motivated human performance appears to the subject as a perezhivanie' (Gonzalez-Rey 2015, p. 9).

Visual methodology used for capturing routine transitions and pivotal transitory moments of infant-toddlers, required consistent video tracking and formation of a trusting relationship with the focus child. In the case example in this paper, the researcher filmed continuously in the babies' room using a small video camera held low at waist level, to provide unobtrusive researcher presence.

Quiñones and Fleer (2011) suggest the researcher forms part of the reality of the child in that moment in time' (p.116) and evident in the video clip example, researcher presence was acknowledged by focus child who occasionally referenced through gazing. This gazing formed "social referencing" behaviour, noted by Sumsion and Goodfellow (2012), p.318 as holding particular social and emotional intention. Focus child Elvin's gazing received smiles in return, however he and two other toddlers in the room, undisturbed by researcher's presence, continued their shared activity connected by gazing and sound.

Video observation, considered an important method in cultural-historical research (Fleer and Ridgway 2014a), allowed researchers to discuss data with participants and one another. Following focus child with video camera for long uninterrupted periods, captured intimate involvement in their experiences and play activity, for future collaborative reflection. In effect, the researcher was immersed in the infants' 'play world' as distinguished from 'the real world' (Singer 2013, p.175). In the Babies' room of the LDC research site, infant-toddlers were immersed in their activity. Sitting unobtrusively a short distance away, researcher (A) video recorded in the manner of naturalistic inquiry (Guba and Lincoln 2005). All dynamic movements and actions, the focus child's relations with two peers and educator, and activity choices in eating, finishing lunch, and playing, were videoed. Later, screen capture snapshots were used to more closely examine educator and toddler's participation and identify nuanced gestures, movements, responses, gazes, relational positions, sustained activity and the wordless expressions of the infant-toddler subjects. In this way, the three researchers could approach this stabilized data with a deeply felt sense of also participating in the experience.

Digital visual technology supported theoretical efforts and added to current knowledge of infant-toddlers by positioning them as social and cultural beings; citizens born into families with different histories, living contexts, and personal situations that bring moods, sensibilities and sensitivities into their world of changing relationships (Vygotsky 1994; Singer and de Haan 2007; Bozhovich 2009).

Video clip data interpretations and discussions (including screen capture snapshots), acknowledged researchers' different perspectives in relation to babies' room activity and pedagogical practices in LDC site. Collaborations supported wider interpretations of the selected video clip. Having contradictory and contrasting experiences and perspectives, enriched the research process by giving opportunity for interpretative and respectful negotiation of what each researcher had noticed. The research team's triadic collaboration was expanded through development of a dialogue commentary that supported our search for social and transformative recombinations in the video clip. Collaboration gave space for deeper understanding of the research team's personal and subjective configurations of the selected video clip. In a cultural-historical sense, 
Gonzalez-Rey (2015) who had recently pointed to thinking more about 'social representation' that would not 'be exhausted by individual subjectivity' (p.1), brought attention to how 'Vygotsky, in his late work, introduced the concept of sense and advanced the concept of perezhivanie as psychological unities whose functioning takes place within the on going living experiences of people' (p.7).

Hard to capture through video alone, the transitory moments of infant-toddlers recorded in the short video clip, were also viewed by LDC educator and director in a reflective interview, as part of a dialectical-interactive research approach.

\section{Reflective interview- Long Day Care (LDC) educator and director}

Reflective interview is an important method Fraenkel and Wallen (2006) suggest, for obtaining data unable to be acquired from video observation alone. With project aims of finding cultural worlds and transitory relationships of infant-toddlers in mind, researchers had selected a relevant video clip to act as prompt for initiating reflective interview responses. Researchers invited comment through asking 'what did you notice in this video clip? The same video clip, shown separately to LDC educator and director, elicited responses according to workplace roles. Pedagogical, community and managerial perspectives were gathered as evidence of wider influences present in the babies' room activity. This gave validation to the process of relevant video clip selection and its use as a research tool for prompting focused reflective interview data. The researchers' collective review of reflective interview data, enabled a 'wholeness' approach to research methodology as discussed by Hedegaard (2008), Li (2014) and Li et al. (2016), and gave better understanding of the perezhivanie (wholly lived emotional experience) of infants, educator and director within the LDC babies' room environment.

Thus, the use of dialectical methodology in research team collaboration, offered opportunity for generating new layers of analysis of research site data for interpretative synthesis to: 'gain a deeper understanding of their pedagogical practices and to analyse for any inherent contradictions and tensions in their practices that could serve as an entry point for initiating pedagogical change' (Yin 2007, p.77).

In the following case example, interpretations of transcript and screen capture snapshot images from LDC babies' room video clip are shared.

\section{Case example- visual narrative of babies' triadic music play experience}

Part of data from the pilot research project Studying Babies and Toddlers:Cultural Worlds and Transitory Relationships, the selected video clip showed three infants under two years of age with educator Jane. Involved in lunchtime routine, two babies had finished lunch and were on the floor with access to musical instruments. Focus child Elvin, (16-months) remained sitting at a small table finishing lunch. He tapped his spoon on his dish. Educator Jane was focused on tidying up and finishing off Elvin's feeding. Elvin's tapping spoon sound filled the room. What happened next exemplified infant-toddler initiated and coordinated triadic play where the immersive soundscape of tapping spoons and shared gazing, joined three babies together in a rhythmic, spontaneously shared, yet intentional, collective experience. A visual narrative follows.

This visual narrative, taken from the video clip using screen capture snapshots, shows how Elvin initiated the action by tapping his feeding spoon against the bowl of food (Fig. 1). 


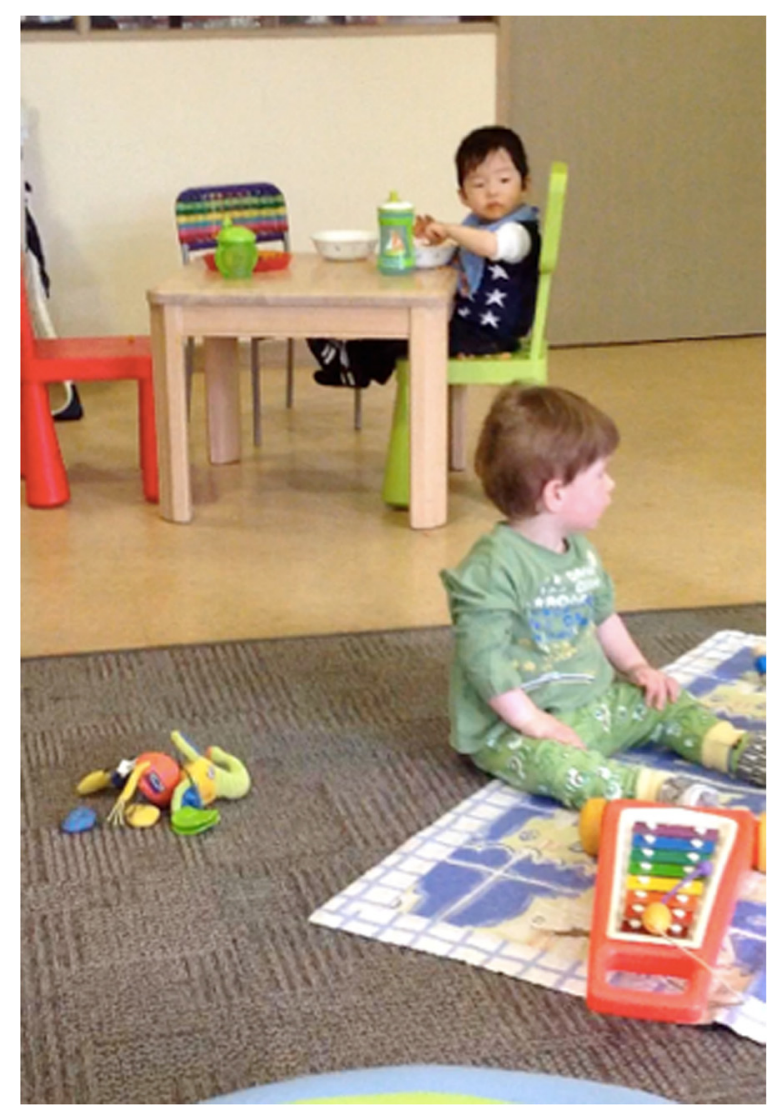

Fig. 1 Elvin starts tapping spoon

On the floor, Josh and Fay alert to Elvin's tapping sound, joined him in a rhythmic tapping game (Fig. 2). In a moment of unconscious imitation educator Jane tapped her serving spoon clean. Her action repeated Elvin's initial spoon tapping.

Elvin continued eating but remained alert to Jane's presence as she smiled (Fig. 3).

He kept tapping and also looked across to Josh in particular who had joined in by producing his own tapping sounds and moving his body side to side in rhythm.

Fay who was on the floor near Josh, was now tapping too and looking towards Elvin who had turned around to gaze at her (Fig. 4). Educator Jane finishing off feeding Elvin, acknowledges the growing action in the room by moving her hands and shoulders.

Elvin's wide gaze (Fig. 5) encompassed his peers who were making the growing tapping sounds around him and then he intentionally tapped his bowl again. Elvin noticed Fay near a small instrument with a beater and Josh tapping on a drum. Elvin's intentional tapping sounds had reached the ears and responsive senses of the whole group including educator, which had the effect of sustaining interest and driving further action. Educator Jane acknowledged this new shared interest between the infants, by singing and moving her own head and shoulders in time to their tapping. Although in different positions, and with different ways of tapping, the three infants created a triadic harmonious ensemble extended by Elvin and joined by their educator (Fig. 5).

The video clip captured for researchers, a cultural, transitory moment of collective endeavour, shared by three infants and their educator, and shared through this visual narrative using screen capture snapshots. 


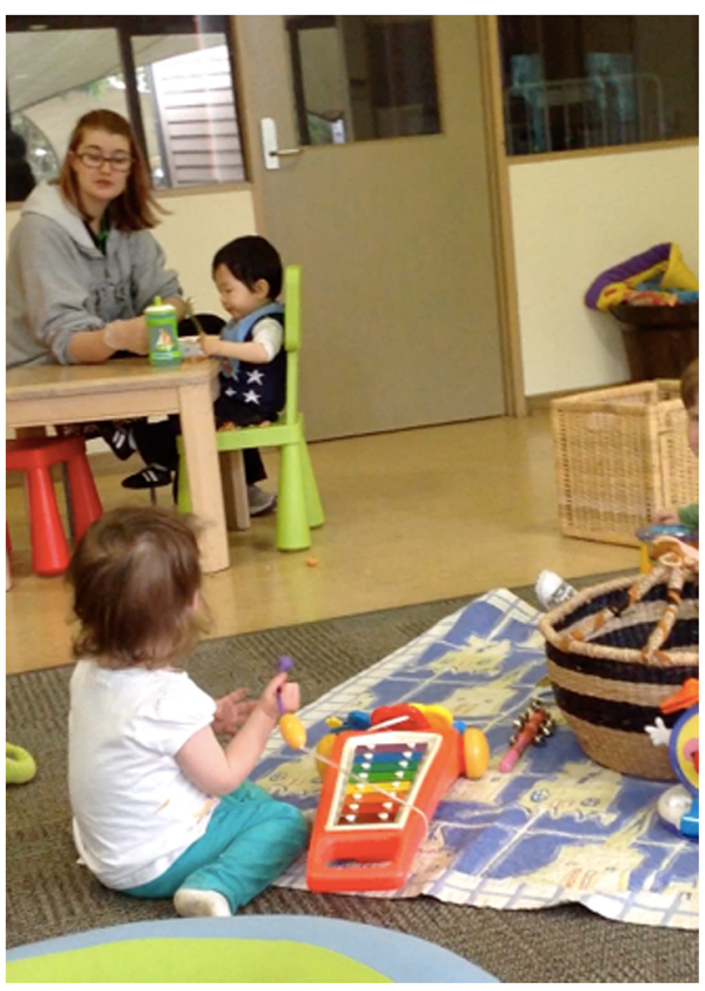

Fig. 2 Peers start to join in using instruments

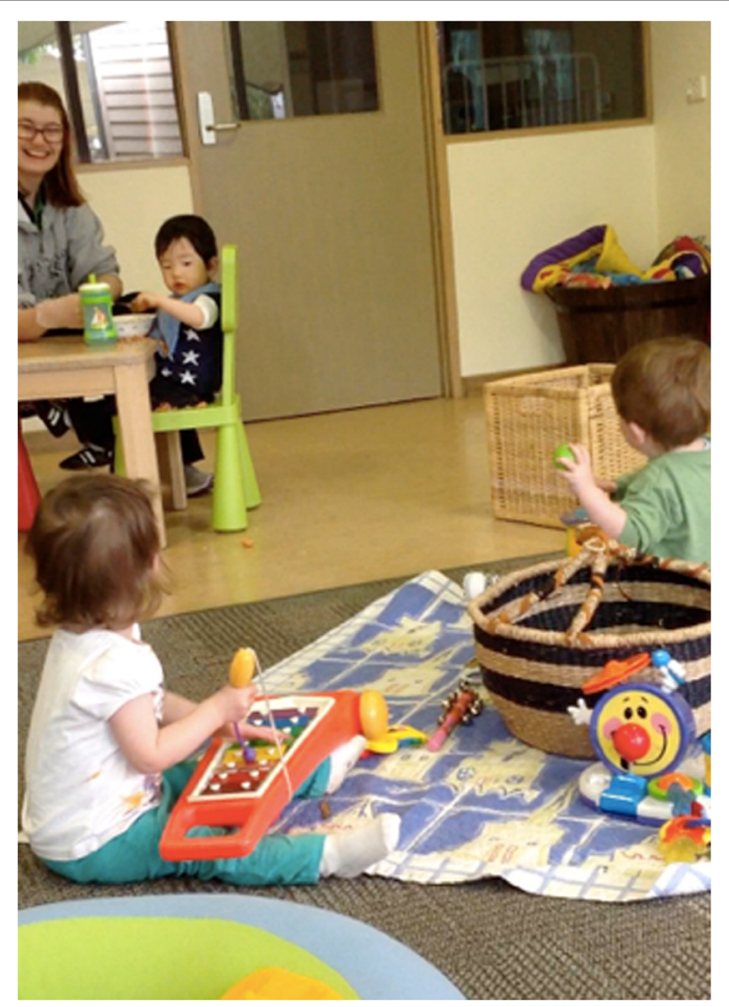

Fig. 3 Educator smiled, Elvin aware of peers 


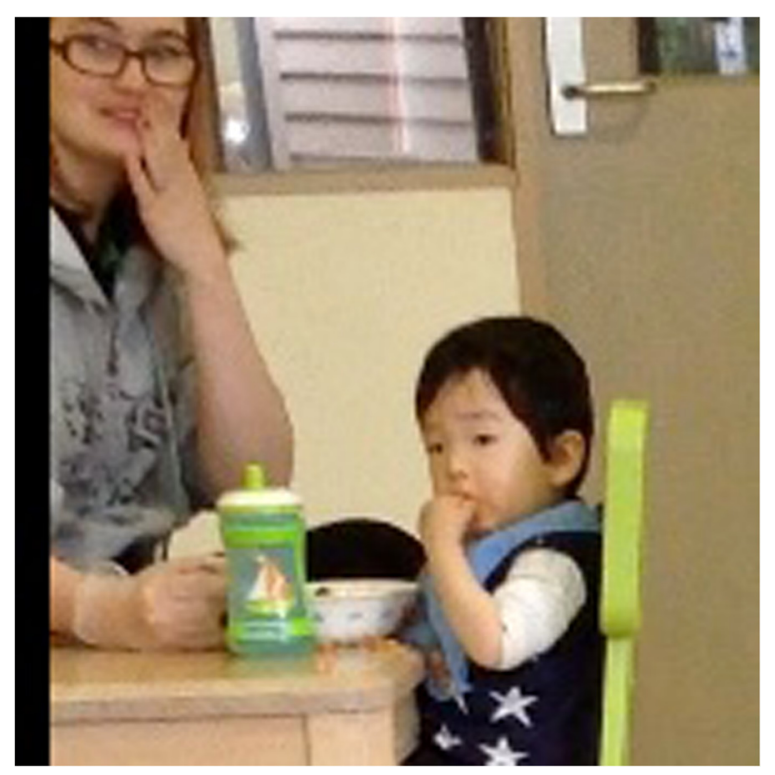

Fig. 4 Educator moved, Elvin gazes at peers

For this infant- toddlers' research, methodological efforts were guided by the cultural-historical concept of perezhivanie. Reviewing the video clip, researchers found this important concept was enhanced through a socially supportive and purpose built play space. The babies' room, located within a building that supported communication, offered participants transparent views. When infants experience their environment in ways that clearly show relationships between individual and collective groupings, visual research methods come to the fore to reveal social practices of gazing and 'place making and place imagining' (Journet and Steier 2015, p.130). This room was an ideal place for video capture of infants' activity to support the research aims of examining how educators recognize cultural worlds

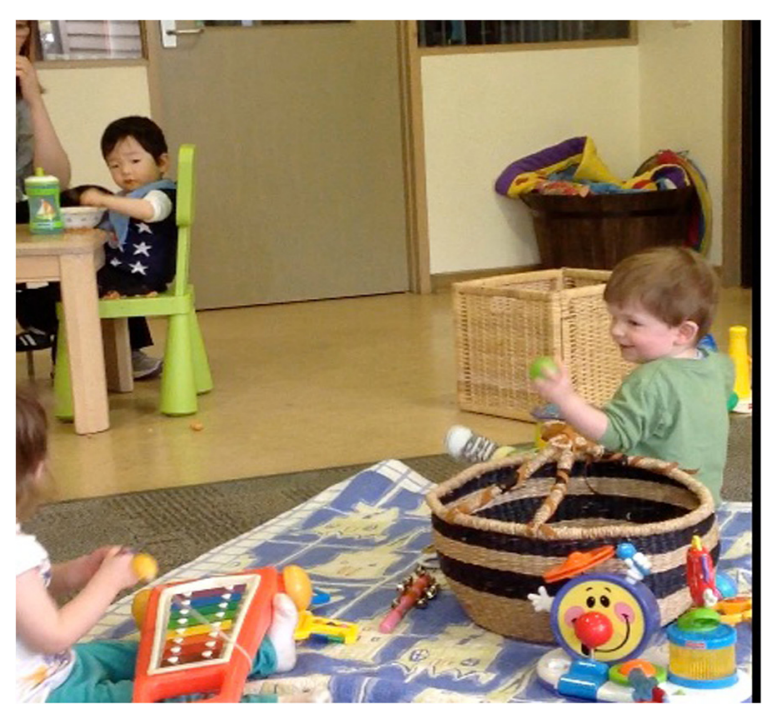

Fig. 5 Elvin aware of leading peers in the triadic musical play 
and transitory relationships of babies and toddlers and how educators may relate to such moments pedagogically.

\section{Visual narrative methodology: capturing infant toddlers' perspective in educational research}

In the pilot study research, the infant-toddlers' perspective was taken to illustrate how babies actively created their own space; a comfortable zone for interactions with others during cultural transitory events, such eating and playing. The selected video clip encompassed such an event, where, the social environment set a playful tone for educator Jane who utilised the room space and materials to further encourage communicative play opportunities for the three infants.

The video clip unexpectedly revealed how purposeful attention given to taking the infant's perspective in the design of the babies' room, had inadvertantly offered pedagogical support for both educator and infants. Observing infant-toddlers situated in this space, invited researchers to carefully feel their way (Lokken 2011) with video data. We later interpreted the video clip through feeling our way using dialogue commentary as a methodological tool.

\section{Dialogue commentary: achieving richness of babies' affective music experience and pedagogical responsiveness}

Validity of pilot project research was partly achieved by the process of dialogue commentary which provided a powerful tool for insight into transitory moments (using screen capture snapshots) of babies' relationships within their social environment.. For creating a dialogue commentary, researchers first observed the babies' room video clip. Each researcher expressed personal reactions, feelings and responses to the video clip and in doing so, created a triadic context for multivoicedness and cultural interpretation of the social context. We contributed to visual narrative methodology by using our interpretative comments that drew on shared cultural historical scholarship. In this way we formed the following dialogue commentary.

\section{A's interpretation}

It's around lunchtime. In the babies' room Jane is feeding Elvin.

Elvin begins tapping his spoon on his dish. Jane achieves shared collective play between the three babies while Elvin eats his lunch and it is achieved through sensitivity to rhythm and music.

A strong sense of togetherness happens. I see the power of Elvin's gaze connecting the group; the sharing of sound, song and movement with spoon, stick, drum and xylophone, body and hands, and Jane's voice and 'moves' as she joins in. Educator Jane enters the play but does not control it. (e.g. she mimicks Josh's shoulder movement). The play is initiated by the triadic group all positioned differently in the room yet aware through socially referencing one another. Josh sits and moves his entire body playfully, smiling so happily.... I see a joyfuness. A perezhivanie forms. Elvin gazes around from sitting position and is always part of the play. 
Although educator is cleaning up, she joins the play, moving her head and body in a spirit of playfulness, that Singer (2013) suggests forms a play pedagogy 'where playfulness co-constructs meaning with infants' (p.182). This movement is recognised by all three infants as being a playful part of their belonging. There is creativity where all participants use what is at hand to express themselves, which appears to help maintain connection between infants especially Josh who responds with excitement to music. The three infants enjoy the collective, deeply felt experience. All positioned differently in the room, they socially reference one another constantly through gaze and hearing. Whilst Elvin is still sitting at the table, the other two babies accept and join the rhythmic opportunity he initiated. It seems to me that what occurs next is a playfully orchestrated, extraordinary expressive performance, of coordinated and rhythmic intensity between the three infants (all under 2 years of age).

When 'making oneself' in relation to others, intentional initiation and reciprocity is involved. Trevarthen (2012), p.303 points to this experience: "Mead and Vygotsky value the social influence, the making of a self in relations with others, and the mastery of cultural tools by highly cooperative, communicating young persons, sharing minds". The three infants enter a self initiated musical performance, a momentary event of sharing minds in triadic play that educator Jane enjoys through joining in with expressive voice and playful movements.

\section{L's interpretation}

I agree with A's comments on three babies' initiation in their own music play. Elvin responds to his peers' (Josh and Fay) music sounds by beating his spoon on the bowl while he is still having his lunch. Another important moment needs to be paid attention to. The conflict takes place between Elvin's affective relations to his friends in music and the educator's attention to his lunch eaten. The educator, Jane does not directly stop Elvin's responses to his peers' music play although she encourages him to keep eating his lunch, rather, she recognized his attention and supported it to make collective music play. Jane moves her body and sings the sounds and three babies are playing their music instruments. The shared music moments happens which shows conceptual reciprocity is achieved.

As Vygotsky (1997) writes "every higher mental function ... was formerly a social relation of two people" (p.105). A social relation appears as a category such as one "emotionally colored and experiencing collision", the contradiction between the two people, and "drama between two individuals" in the dramatic event (Veresov 2004, p.19). Pedagogically, the educator is insightful about her babies' needs and interests and makes a playful joint engagement. As a result, three babies make the triadic music play by reading each other's music responses. The shared togetherness is formed in the end.

\section{G's interpretation}

This moment is about the educator and children forming a sense of togetherness that is created to musical rhythm. This is a meaningful experience for all children, there is playfulness and very young children like Elvin, Josh and Fay are able to 
communicate their interest of musicality together by Elvin playing with spoon and constantly looking back to Fay and Josh and Fay looking at Elvin in a very special triadic way. This is a special magical moment as the educator Jane is able to understand these patterns of rhythm and interaction and support children's agency. She also extends, shows interest and creates a sense of togetherness with each child and the whole group.

Singer (2013), p.182 explains how "very young children communicate with the teacher in order to make contact, i.e. to construct a shared magical world in which the child feels safe and valued. Ritualized interactions or patterns of behavior help the child to anticipate, to take initiative and invent variations; they support the child's agency". Jane is pedagogical in reading children's initiative without overtaking and also by supporting children and making them feel safe and valued through responding by dancing and moving while sitting with Elvin finishing his lunch; by singing with Fay, and by encouraging Josh with his moves and saying "I like your moves". She is a sensitive and affective educator who is able to invent and co-invent with children, music and movement and support their agentic initiations.

This dialogue commentary shows the complexity of the infants' interactions. When the three researchers made their own responses to each other's comments they took a different personal focus on the same video clip. A dialectical-interactive methodology offered a process that brought a richer understanding of visual data in relation to research aims. The critical analysis achieved by use of dialogue commentary is shown in Table 2.

Table 2 Analysis of researchers' dialogue commentary

\begin{tabular}{|c|c|c|c|}
\hline $\begin{array}{l}\text { Dialogue } \\
\text { commentary }\end{array}$ & Infants'engagement & Educator's interaction & Pedagogical strategies \\
\hline \multirow[t]{3}{*}{ A } & $\begin{array}{l}\text { Self-initiated music } \\
\text { performance }\end{array}$ & $\begin{array}{l}\text { Aware and responsive } \\
\text { at all times }\end{array}$ & $\begin{array}{l}\text { Percussion instruments } \\
\text { made available }\end{array}$ \\
\hline & $\begin{array}{l}\text { Three babies respond } \\
\text { to one another through } \\
\text { senses - moving, seeing, } \\
\text { hearing - rhythm, gaze, } \\
\text { sound. }\end{array}$ & $\begin{array}{l}\text { Entering play without } \\
\text { controlling it }\end{array}$ & $\begin{array}{l}\text { Social referencing, being } \\
\text { playful together as part of } \\
\text { group belonging }\end{array}$ \\
\hline & $\begin{array}{l}\text { An experience that is } \\
\text { collective, deeply felt } \\
\text { and lived. (perezhivanie) }\end{array}$ & $\begin{array}{l}\text { Joins play, moving head } \\
\text { and body in a spirit } \\
\text { of playfulness }\end{array}$ & $\begin{array}{l}\text { Using power of shared sound } \\
\text { and movement in a calm } \\
\text { pedagogically } \\
\text { supportive environment }\end{array}$ \\
\hline \multirow[t]{3}{*}{ L } & $\begin{array}{l}\text { Babies'initiation of } \\
\text { the music play }\end{array}$ & $\begin{array}{l}\text { Moves her head and body, } \\
\text { and sings the sounds along } \\
\text { with the babies' music play }\end{array}$ & $\begin{array}{l}\text { Acknowledgement of babies' } \\
\text { initiation }\end{array}$ \\
\hline & Affective relations & Joint play & Joint communication by music \\
\hline & $\begin{array}{l}\text { Elvin's interest in the } \\
\text { peers' music play }\end{array}$ & $\begin{array}{l}\text { Demands in Elvin's } \\
\text { lunch eaten }\end{array}$ & $\begin{array}{l}\text { Take Elvin's perspective and } \\
\text { support to make a } \\
\text { collective play }\end{array}$ \\
\hline \multirow[t]{3}{*}{ G } & \multirow{2}{*}{$\begin{array}{l}\text { Collective affective musical } \\
\text { and relational experience. } \\
\text { Agentic moment }\end{array}$} & $\begin{array}{l}\text { Creating a sense of } \\
\text { togetherness }\end{array}$ & Encouraging \\
\hline & & Safe and valued environment & $\begin{array}{l}\text { Valuing children's interests } \\
\text { and initiatives }\end{array}$ \\
\hline & $\begin{array}{l}\text { Babies responding to } \\
\text { each other's patterns of } \\
\text { interaction and initiation }\end{array}$ & & $\begin{array}{l}\text { Taking part in the musicality } \\
\text { by moving, singing and } \\
\text { looking (gaze) at all children }\end{array}$ \\
\hline
\end{tabular}


Importantly, the video clip was a common reference point for generating the dialogue commentary. Table 2 analysis demonstrates rich understandings of three babies' transitory moments and their educator's interactions in the group play, that generated a shared musical experience. Researchers discovered educator Jane's pedagogical responses to transitory moments, and also how she recognized infants' cultural worlds and transitory relationships in the LDC babies'room.

Developing a dialogue commentary proved a practical methodology for researchers as it formed reflection in action, which gave cultural interpretations of the experience recorded in video clip data, and when combined with the use of visual narrative snapshots, offered a way to reconfirm research aims of the pilot study.

Reflective practice, mandated in Australian early childhood learning frameworks (DEEWR 2009), was familiar to research site educator and director. Their reflections on the video clip formed a key component of the pilot project's methodology by providing further opportunity to achieve its aims, and are discussed next.

\section{Reflective interview: achieving multiple perspectives of babies' triadic play}

In order to achieve objectivity and validity, reflective interviews were undertaken with LDC director and Babies' room educator. The video clip of the transitory moments of triadic play between Elvin, Josh and Kay with educator Jane, prompted reflective interview conversations. Both educator and director's reflective interviews yielded wider pedagogical perspectives than imagined. The inclusion of their reflective interviews in the pilot project's methodology brought attention to some personal, pedagogical and organisational qualities. Director Kate commented on responsiveness and respectfulness after viewing the video clip of babies' room educator Jane and the three infants:

I can see the responsiveness that Jane has with the children and being able to spend and be attentive across those three children is really lovely to see and I don't get to see that a lot so it's interesting for me to see it from a different perspective and the gentle encouragement that she is showing the children is so fine and probably delicate that a lot of people wouldn't notice - getting extra spoons - that Elvin can use the spoon as well and talking to him as he's eating and finding that time.

The responsiveness director Kate refers to, provided evidence for researchers of the presence of an important pedagogical approach used by educator Jane; that of being responsive when working with infant-toddlers. It was because of Jane's responsiveness, that the infants were able to play reciprocally. Director Kate also alluded to the importance of educator Jane's respectfulness in her pedagogical approach to working with infants. In relation to Jane and Elvin she noted:

Yeah and the respectfulness in this is really something that I guess I'm really proud of that I can see in here and giving him that time and spending that time to talk to him, and she didn't leave him -she sat down and supported him through to the end of that experience. 
Using the method of reflective interview brought contextual findings to this research. One example was the discovery of director Kate's strong aspirations for all children and staff in the LDC site. Her understanding of staff member Jane and acknowledgement of the respect and care given to Elvin, became evident when she noted:

When you're in a room by yourself with three children it's quite busy but finding that time and continuing encouraging him to eat and then sitting down and spending that time with him to make sure that he's supported through that is really interesting, and then that responsiveness to the other children and engaging all of them in that conversation and in those experiences and Elvin just tap tap tap tap tap.

Videoing in the Babies' room revealed a level of transparency in site design, rarely seen in LDC. In educator Jane's reflective interview, this special quality was mentioned: 'the space allows for transitions and it prepares the children for them. They can see in a good secure safe place...' Hence, the reflective interview with video prompt, provided new data that revealed hidden pedagogical qualities of the research site design. Findings that met the project's aims included revelations of action resulting from wide gaze awareness in communication strategies, seeing respectfulness in transitory learning moments and showing educator's pedagogical awareness of the group of infants.

When educator Jane responded to video prompt for the reflective interview, her involvement in the video clip was personal. The transcript shows her pedagogical thoughts at the time were about cleaning away and finishing off lunch. Initially triadic connections, encouraging awareness and transitory learning moments between the infants, were not uppermost in Jane's mind:

The connections and music between friends and looking at each other and looking back at each other...between observing and oooohh being a collective group....at that point in time I was more concerned about getting Elvin to eat his lunch... you've got to eat some food.

Using visual methodology for interview prompt, provided relevant feedback on pedagogical thought that heightened educator Jane's awareness of infant-toddlers' perspectives and their capacity to initiate collective learning in triadic play activity:

In my head was Elvin to eat his lunch and stop being distracted but it wasn't really a distraction it was a learning moment. Elvin was doing a lot of things I didn't realise that he was doing at that point in time.

From Jane's perspective, reflecting on the video clip transformed pedagogical awareness.

Using visual methodology for reflective interviews with educator and director also provided researchers with opportunity for analysis (Table 3) for a richer understanding of interactions and pedagogical strategies practised with babies in the LDC site. 
Table 3 Educators' reflective interviews

\begin{tabular}{llll}
\hline Reflective interview & Infant's engagement & Educator's interaction & Pedagogical strategies \\
\hline Kate - director & $\begin{array}{l}\text { Routine lunch, } \\
\text { and play }\end{array}$ & Responsiveness & Respectfulness \\
& & Gentle encouragement & Knowledge of staff \\
& Being attentive & Knowledge of infants \\
Jane- educator & Learning connections & Focus on Elvin eating & $\begin{array}{l}\text { Sensitivity to learning } \\
\text { moments }\end{array}$ \\
& Materials at hand & $\begin{array}{l}\text { Supervising group } \\
\text { Improvisation Participation }\end{array}$ & Awareness of whole group \\
& Calm atmosphere & A & \\
\hline
\end{tabular}

Linking researcher's dialogue commentary to reflections of educator and director showed how infant-toddler Elvin's engagement in routine lunch and play was connected with educator sensitivity. Her provision of a calm, respectful and nurturing atmosphere created affective relations in a culturally constructed event that held rhythmic intention expressed between the three infants and their educator.

Using video methodology to produce visual narratives, dialogue commentary and prompt reflective interviews showed how a transitory moment of transformation of action could be captured. Data from video clip reflective interviews gave evidence that with caring and sensitive support of an educator, infants under two years of age were capable of reciprocating expressive movements and imitating sound in a triadic form of connected, pleasurable, rhythmic and deeply felt perezhivanie.

\section{Conclusion}

Vygotsky wrote in 1930 of the problems of construction and genesis of higher mental functions referring in particular, to the child's symbolic activity, which in his view, was formed in an historical, social and cultural process. "The uniting points of the whole system that determine the relation to it of one specific mental process or another, is the common quality of their origin, structure, and function" (Vygotsky 1999 (3) p. 40).

Visual narrative methodology in educational research with babies, as discussed in this paper, created visual narratives and dialogue commentary validated through reflective interview. This process involved researchers in building holistic views elaborated through a video clip case example of the nature and context of infants' educational experience in the LDC site.

The researchers' own triadic collaborations brought a dialectical- interactive wholeness approach, that aimed to illuminate the multiple perspectives existing in the world of infant-toddler's and unite those different perspectives in the task of finding infants' voice.

Two well-known scholars' science work (Keller and McClintock) examined by Fleer (2014) in relation to methodological approaches, suggest three important research dimensions:

1. To create a sense of the oneness with what is being studied

2. To give an holistic or 'a oneness' view of research, rather than reducing and studying all the elements in separate categories

3. To study the connectivity of the system giving new insights (Fleer 2014, p.4) 
The methodological approaches used in relation to our video case example, showed this sense of oneness that Fleer refers to. Researchers' triadic analysis of a collaboratively chosen video clip data to create dialogue commentary, brought together multiple perspectives on what was being studied, and highlighted throughout this paper.

The holistic view taken by researchers to participants and contexts in this pilot study led to identification and extrapolation of cultural worlds and transitory moments that lead to learning opportunities for infants. This was achieved through selection of one video clip as a common point of reference that united the research. It brought together visual narrative methodology used to create subsequent dialogue commentary, with prompted reflective interviews which, when combined were powerful research tools for insights into the infants' cultural worlds and transitory moments. Our new insights have pedagogical implications related to importance of educator awareness, playfulness, respectfulness and provision of a well designed site for calm and comfortable socialisation for infants' learning.

The idea of formation of triadic play in infancy was fully evident in the case study video clip and in other video data from the wider project. This has challenged researchers to rethink views of parallel play in infancy, when video evidence shows collective (in this case example, triadic play), was prominent in the pilot project study site. For early childhood education policy makers, centre directors and educators of infanttoddlers in LDC settings, these views form important findings for future consideration.

In summary, the use of experimental visual research methodology produced data, that when dialectically juxtaposed, validated the research. For example when we read the researcher's dialogue commentary analysis (Table 2), we noted the educator's sensitive interaction and awareness of changes to infant's moments of engagement as a whole group. This connected directly to the analysis of educator's reflective interview (Table 3), where the director had commented on the educator's responsiveness and encouragement of the infants, in pedagogically respectful ways - such as giving time to finish eating. The educator herself reflected on improvising participation with individuals and the whole group, and showing awareness and sensitivity to particular learning moments for the infants in her care, that involved music and movement.

In conclusion, the triadic research team suggest that the experimental technique of visual narrative methodology and dialogue commentary, with reflective interview, offered a powerful combination of methodologies capable of illustrating ways to recognize the cultural worlds and transitory relationships of infant- toddlers, and show how transitory moments are related to pedagogically by educator, director, children and researchers.

Competing interests

The authors declare that they have no competing interests.

All authors are co-investigators of project led by LL. In the case of this paper AR, took lead and made first draft of the manuscript, and later edited the whole. Co-authors LL and GQ comprehensively and collaboratively supported and extended this work. All authors read and approved the final manuscript prior to submission. 
Received: 21 October 2015 Accepted: 8 March 2016

Published online: 02 August 2016

\section{References}

Bitou A, Waller T (2011) Researching the rights of children under three years old to participate in the curriculum in early years education and care. In: Harcourt D, Perry B, Waller T (eds) Researching young children's perspective: Debating the ethics and dilemmas of educational research with children. Routledge, New York, pp 52-67

Bozhovich LI (2009) The social situation of child development. J Russ East Eur Psychol 47:59-86

Denzin NK, Lincoln YS (eds) (2003) Collecting and interpreting qualitative materials, 2nd edn. SAGE Publications, Thousand Oaks, London, Delhi

Department of Education, Employment and Workplace Relations (DEEWR) (2009) Belonging, being and becoming: the early years learning framework for Australia. Australian Government, Canberra

Ferholt B (2010) A synthetic-analytic method for the study of perezhivanie: Vygotsky's literary analysis applied to playworlds. In: Connery MC, John-Steiner VP, Marjanovic-Shane A (eds) Vygotsky and creativity, a cultural-historical approach to play, meaning making and the arts. Peter Lang, NewYork, pp 163-179

Fleer M (2014) A digital turn: Post-developmental methodologies for researching with young children. In: Fleer M, Ridgway A (eds) Visual methodologies and digital tools for researching with young children: transforming visuality. Springer, Dordrecht, pp 3-14

Fleer M, Ridgway A (eds) (2014) Visual methodologies and digital tools for researching with young children: transforming visuality. In: International perspectives on early childhood education and Development 10. Springer, Dordrecht

Fraenkel JR, Wallen NE (2006) How to design and evaluate research in education, 6th edn. McGraw-Hill, Boston

Gonzalez-Rey, F. (2015) A new path for the discussion of Social Representations: Advancing the topic of subjectivity from a cultural-historical standpoint. Theory \& Psychology 1-19 sagepub.co.uk/journals DOl: 10.1177/ 0959354315587783 tap.sagepub.com

Guba EG, Lincoln YS (2005) Paradigmatic controversies, contraditions, and emerging confluences. In: Denzin NK, Lincoln YS (eds) The SAGE handbook of qualitative research, 3rd edn. Sage Publications, Thousand Oaks, pp 191-217

Hedegaard M (2008) Developing a dialectic approach to researching children's development. In: Hedegaard M, Fleer M, Bang J, Hviid P (eds) Studying children: A cultural-historical approach. Open University Press, Maidenhead, pp 30-45, New York

Johansson E, White J (eds.) (2011) Introduction: Giving Words to Children's Voices in research. In: Educational Research with Our Youngest. Voices of Infants and Toddlers. Springer, Dordrecht

Johansson E (2011) Investigating morality in Toddler's Life-Worlds, 3 (39-62). In: Johansson E, White EJ (eds) Educational research with our youngest: Voices of infants and toddlers. Springer, Dordrecht, Heidelberg, London, NewYork

Journet A, Steier R (2015) The matter of space: Bodily performances and the emergence of boundary object during multidisciplinary design meetings. Mind Cult Act 22(2):129-151. doi:10.1080/10749039.2015.1024794

Kupfer H (2011) Children's voices in early childhood settings' everyday concerts. In: Harcourt D, Perry B, Waller T (eds) Researching young children's perspective: Debating the ethics and dilemmas of educational research with children. Routledge, NewYork, pp 100-112

Li L (2014) A visual dialectical methodology: using a cultural-historical analysis to unearth the family strategies in children's bilingual heritage language development. In: Fleer M, Ridgway A (eds) Visual methodologies and digital tools for researching with young children: Transforming visuality., pp 35-53

Li L, Quiñones G, Ridgway A (eds) (2016) Studying babies and toddlers: Relationships in cultural worlds. Springer, Dordrecht

Lokken, G. (2011) Lived experience as an observer among toddlers Ch 8 pp161-183 In E. Johansson, E.J. White (eds.), Educational Research with Our Youngest, International Perspectives on Early Childhood Education and Development 5, DOI 10.1007/978-94-007-2394-8_8, C_ Springer Science+Business Media B.V.

Malloch S, Trevarthen C (eds) (2009) Communicative Musicality. Exploring the babies of human companionship. Oxford University Press, Oxford

Quiñones G (2014) A visual and tactile path: Affective positioning of researcher using a cultural- historical visual methodology. In: Fleer M, Ridgway A (eds) Visual methodologies and tools for researching with young children. Springer, Netherlands, pp 111-128

Quiñones G, Fleer M (2011) "Visual Vivencias": A cultural-historical tool for understanding the lived experiences of young children's everyday lives. In: Johansson E, White J (eds) Educational research with our youngest: Voices of infants and toddlers. Springer, Netherlands, pp 107-129

Ridgway A, Quiñones G, Li L (2015) Early childhood pedagogical play: A cultural-historical interpretation using visual methodology. Springer Science, Singapore

Rinaldi C (2000) Creativity as a quality of thought. Ch. 10. (111-120). In: Gunilla D, Peter M (eds) Dialogue with Reggio Emilia, listening, researching and learning (contesting early childhood series). Routledge Taylor and Francis Group, London and New York

Selby JM, Bradley BS (2003) Infants in groups: A paradigm for the study of early social experience. Hum Dev 46:197-221

Sikder S, Fleer M (2015) Small science: Infants and toddlers experiencing science in everyday family life. Res Sci Educ 45(3):445-464. doi:10.1007/s11165-014-9431-0

Singer E (2013) Play and Playfulness, basic features of early childhood education. Eur Early Child Educ Res J 21(2):172-184

Singer E, de Haan D (2007) The social lives of young children. Play, conflict and moral learning in day-care groups. SWP, Amsterdam

Sumsion, J. \& Goodfellow, J. (2012) 'Looking and listening in': a methodological approach to generating insights into infants' expriences of early childhood education and care settings. European Early Childhood Education Research Journal 20 (3) 313-327, Routledge: Taylor \& Francis Group. 
Sumsion J, Harrison L, Press F, McLeod S, Goodfellow J, Bradley B (2011) Researching infants' experiences of early childhood education and care. In: Harcourt D, Perry B, Waller T (eds) Researching young children's perspective: Debating the ethics and dilemmas of educational research with children. Routledge, New York, pp 113-127

Sumsion J, Bradley B, Stratigos T, Elwick S (2014) 'Baby cam' and participatory research with infants: A case study of critical reflexivity. In: Fleer M, Ridgway A (eds) Visual methodologies and digital tools for researching with young children: transforming visuality. Springer, Dordrecht, pp 169-192

Trevarthen C (2012) Editorial, Finding a place with meanings in a busy human world: how does the story begin, and who helps? Eur Early Child Educ Res J 20(3):303-312

Veresov, N. (2004) Zone of proximal development (ZPD): The hidden dimension? Ostern, A. \& Heila-Ylikallio, R. (eds.). Sprak som kultur - brytningar I tid och rum. - Language as culture - tensions in time and space. (1), 13-30, VASA.

Vygotsky LS (1987) The development of scientific concepts in childhood (N. Minick, Trans.). In: Rieber RW, Carton AS (eds) The collected works of L.S. Vygotsky, vol 1. Plenum Press, New York, pp 167-241

Vygotsky L (1994) The problem of the environment. In: van der Veer R, Valsiner J (eds) The Vygotsky reader. Blackwell, Oxford UK, Cambridge USA, pp 338-339

Vygotsky LS (1997) Genesis of higher mental functions. In: Rieber RW (ed) The collected works of L. S. Vygotsky: The history of the development of higher mental functions, vol 4. Plenum Press, New York, pp 97-119

Vygotsky, L.S. (1999) Sign operation and organisation of mental processes. In: R.W. Rieber (ed.), The collected works of L.S. Vygotsky: Scientific legacy (6), Ch. 3, 39- 44. Springer Science + Business Media, LLC.

White EJ (2011) 'Seeing' the toddler: Voices or voiceless? In: Johansson E, White EJ (eds) Educational research with our youngest: Voices of infants and toddlers. Springer, Dordrecht, pp 63-86

Yin A (2007) What's the use of "Triadic Dialogue"?: Activity theory, conversational analysis and analysis of pedagogical practices. Pedagogies: An Int J 2:77-94. doi:10.1080/15544800701343943

\section{Submit your manuscript to a SpringerOpen ${ }^{\circ}$ journal and benefit from:}

- Convenient online submission

- Rigorous peer review

- Immediate publication on acceptance

- Open access: articles freely available online

- High visibility within the field

- Retaining the copyright to your article

Submit your next manuscript at $\gg$ springeropen.com 